To Maega | Jurnal Pengabdian Masyarakat

Oktober 2021, Vol.4, No.3, hal, 255-262

$\operatorname{ISSN}(P): 2622-6332 ; \operatorname{ISSN}(E): 2622-6340$

http://www.ojs.unanda.ac.id/index.php/tomaega

\title{
Pelatihan Pengkayaan Pakan Pada Kelompok Pembudidaya Udang Sistem Backyard Di Kabupaten Barru
}

\author{
Asni Anwar 1, Murni 1, Darmawati ${ }^{1}$, Abdul Malik ${ }^{1}$, Andi Khaeriyah ${ }^{1}$, \\ Hamsah ${ }^{1 *}$, Muhamad Ikbal ${ }^{1}$ \\ ${ }^{1}$ Budidaya Perairan, Fakultas Pertanian, Universitas Muhammadiyah Makassar \\ *Correspondent Email: hamsahadali@unismuh.ac.id
}

Article History:

Received: 12-08-2021; Received in Revised: 29-08-2021; Accepted: 21-09-2021

DOI: http://dx.doi.org/10.35914/tomaega.v4i3.787

\begin{abstract}
Abstrak
Masyarakat di wilayah pesisir Desa Madello Kecamatan Balusu Kabupaten Barru memanfaatkan pekarangan rumah sebagai tempat budidaya udang vaname skala pembenihan melalui sistem backyard. Kendala utama yang sering dialami oleh kelompok pembudidaya udang "Pantai Palie" Desa Madello adalah rendahnya kelulushidupan udang yang umumnya terjadi pada fase mysis ke fase pascalarva, sehingga perlu penerapan teknologi tepat guna untuk meningkatkan hasil panennya. Salah satu upaya yang dilakukan untuk menyikapi masalah tersebut adalah menerapkan penggunaan prebiotik mannanoligosakarida (Bio-MOS) pada pakan alami Artemia sp. sebagai pakan larva udang untuk meningkatkan nilai nutrisi pakan. Metode pelaksanaan kegiatan dilakukan dengan metode diskusi, koordinasi, penyuluhan, pelatihan dan pendampingan kepada mitra. Berdasarkan hasil kegiatan pengabdian kepada masyarakat, kelompok pembudidaya udang "Pantai Palie" menjadi mengetahui dan terampil melakukan pengkayaan pakan alami Artemia sp. dengan Bio-MOS, sehingga dapat meningkatkan kelulushidupan udang pada stadia mysis ke pascalarva. Saran yang diberikan dalam kegiatan ini adalah sebaiknya dilakukan pendampingan lanjutan terkait penggunaan BioMOS pada pakan Artemia sp. serta pelatihan manajemen usaha untuk meningkatkan kualitas sumberdaya manusia sebagai pengelola pada usaha pembenihan sistem backyard di Desa Madello,Kabupaten Barru.
\end{abstract}

Kata Kunci: udang vaname, backyard, Artemia sp., mannanoligosakarida (Bio-MOS).

\section{Abstract}

Communities in the coastal area of Madella Village, Balusu District, Barru Regency use their home yards as a place for cultivation vanname shrimp on a hatchery scale through the backyard system. The main obstacle that is often experienced by the "Palie Beach" shrimp farming group is the low survival rate of shrimp, which generally occurs from the mysis phase to the postlarva phase, so it is necessary to apply appropriate technology to increase crop yields. One of the efforts made to address this problem is to apply the use of prebiotic mannanoligosaccharides (Bio-MOS) in natural feed Artemia sp. as feed for shrimp larvae to increase the nutritional value of feed. The method of implementing the activities is carried out using the methods of discussion, coordination, counseling, training and mentoring to partners. Based on the results of community service activities, the "Palie Beach" shrimp farming group became aware of and skilled in enriching the natural feed of Artemia sp. with Bio-MOS, so that it can increase the survival of shrimp from the mysis stage to post-larvae. The advice given in this activity is that further 
assistance should be carried out regarding the use of MOS in Artemia sp feed as well as business management training to improve the quality of human resources as managers in a backyard hatchery business in Madello Village, Barru Regency.

Key Word: vanname shrimp, backyard, Artemia sp., mannanoligosaccharides (Bio-MOS).

\section{Pendahuluan}

Pembenihan udang vaname pada panti pembenihan (hatchery) atau panti pembenihan skala rumah tangga (backyard) maupun pembenihan skala besar sangat menentukan ketersediaan benur udang yang bebas penyakit dan berkualitas untuk menunjang tingkat keberhasilan budidaya udang di Indonesia. Kegiatan pembenihan udang vaname dilakukan mulai pada perkembangan larva udang vaname sejak menetas sampai post larva atau pascalarva yaitu nauplius, zoea, mysis dan pascalarva (PL). Menurut Panjaitan dkk, (2015) bahwa keberhasilan dalam sistem pembenihan udang sangat dipengaruhi oleh tiga faktor utama, yaitu pakan, lingkungan (media pemeliharaan) dan biota. Keberhasilan pembenihan melalui aplikasi immunostimulan terhadap larva udang pada kegiatan pembenihan skala rumah tangga telah dilakukan oleh Mahasri dkk, (2014) dan dilaporkan bahwa terjadi meningkatkan produksi dengan adanya peningkatan ketahanan tubuh udang dan perlindungan dimasa pembenihan udang.

Desa Madello Kecamatan Balusu Kabupaten Barru terletak di wilayah pesisir dengan luas wilayah $721 \mathrm{Ha}$. Masyarakat yang berdomisili di Desa Madello, umumnya memiliki mata pencaharian sebagai nelayan dan adapula yang melakukan usaha pembenihan udang skala rumah tangga (backyard) dengan memanfaatkan halaman rumah sebagai lokasi usaha. Para pembudidaya udang skala rumah tangga di Desa Madello tergabung dalam beberapa kelompok, satu diantaranya adalah kelompok "Pantai Palie" dengan jumlah anggota 6 orang. Usaha pembenihan pada kelompok Pantai Palie dimulai sejak tahun 1990 an dengan cara membeli naupli dari perusahaan pembenihan (hatchery) skala besar kemudian membudidayakan hingga fase pascalarva, selanjutnya dijual kepada para pembudidaya untuk pembesaran udang.

Berbagai kendala masih dihadapi oleh kelompok pembudidaya udang vaname skala rumah tangga di Desa Madello termasuk kelompok "Pantai Palie". Kendala utama yang sering dialami oleh kelompok pembudidaya udang Pantai Palie adalah rendahnya kelulushidupan larva udang pada fase mysis ke fase pascalarva yaitu hanya sekitar $45 \%$, sehingga perlu penerapan teknologi tepat guna untuk meningkatkan hasil panennya. Salah satu upaya yang dilakukan untuk menyikapi masalah tersebut adalah menerapkan penggunaan prebiotik mannanoligosakarida (Bio-MOS). Hamsah dkk, (2018) dan Hamsah dkk, (2019) melaporkan bahwa pemberian prebiotik mannanoligosakarida (MOS) yang diaplikasikan pada pakan alami Artemia sp., merupakan salah satu cara untuk meningkatkan pertumbuhan dan respons imun udang sejak stadia larva, sehingga udang memiliki daya tahan terhadap penyakit (specipik pathogen resistence) dan license (https://creativecommons.org/licenses/by-sa/4.0/). 
dapat meningkatkan keberhasilan pembenihan udang. Selanjutnya saat benih udang ditebar di tambak pembesaran, telah memiliki respons pertumbuhan dan sistem imun yang lebih baik untuk menghadapi serangan berbagai pathogen yang terdapat pada kondisi lapang di tambak.

Penerapan iptek berupa pengkayaan pakan alami Artemia sp. dengan prebiotik mannanoligosakarida (Bio-MOS) pada pembenihan udang vaname skala rumah tangga (backyard) di Desa Madello untuk meningkatkan hasil panen benih/benur udang menjadi tujuan dari kegiatan pengabdian ini. Keberlanjutan kegiatan penyuluhan dan pelatihan ini sangat diharapkan oleh pembudidaya sehingga terjadi transfer iptek mengenai tehnik pengkayaan pakan dan manajemen pembenihan udang vaname antara Perguruan Tinggi khususnya dari tim dosen budidaya perairan Universitas Muhammadiyah Makassar dengan masyarakat pembudidaya udang di Desa Madello Kabupaten Barru.

\section{Metode}

Pelaksanaan kegiatan dilakukan pada hari kamis tanggal 8 Juli 2021, bertempat di halaman rumah ketua kelompok Pantai Palie. Jumlah peserta pelatihan 10 orang yang terdiri dari anggota kelompok Pantai Palie dan karyawan backyard. Kegiatan ini juga melibatkan dua orang mahasiswa program studi Budidaya Perairan Fakultas Pertanian Universitas Muhammadiyah Makassar yang ikut membantu dalam pelaksanaan kegiatan pengabdian masyarakat.

Metode pelaksanaan yang diterapkan untuk membantu mitra dalam mengatasi permasalahan yang dihadapi adalah sebagai berikut:

1. Melakukan diskusi dengan mitra untuk mengetahui beberapa permasalahan yang dihadapi, selanjutnya dilakukan identifikasi permasalahan-permasalahan pokok yang dihadapi oleh mitra. Membuat kesepakatan antara mitra dan tim pelaksana untuk memilih permasalahan yang akan diselesaikan melalui kegiatan pelaksanaan pengabdian kepada masyarakat

2. Melaksanakan koordinasi dengan ketua kelompok pembudidaya untuk menentukan waktu dan tempat pelaksanaan kegiatan.

3. Melaksanakan penyuluhan tentang pengenalan dan peningkatan kelulushidupan dan pertumbuhan larva udang dengan melakukan pengkayaan pakan alami Artemia sp. menggunakan prebiotik mannanoligosakarida (BioMOS).

4. Melaksanakan pelatihan tentang penggunaan prebiotik Bio-MOS pada budidaya udang vanname. Kegiatan ini dilakukan pada kelompok pembudidaya udang Pantai Palie yang berlokasi di Desa Madello Kecamatan Balusu Kabupaten Barru. Materi pelatihan yang diberikan meliputi materi pengenalan dan penggunaan prebiotik Bio-MOS (Altech inc., KY USA) yang mengandung mannanoligosakarida (MOS).

5. Kegiatan ini dimaksudkan agar mitra memiliki pengetahuan dan keterampilan dalam meningkatkan kelulushidupan udang pada saat pembudidayaan. 
6. Melaksanakan pendampingan, kegiatan ini dilaksanakan untuk menjamin keberlanjutan program serta memastikan dapat melaksanakan kegiatan sesuai yang telah direncanakan.

\section{Hasil dan Pembahasan}

Kegiatan ini diawali dengan melaksanakan survey dan koordinasi kepada mitra pada tanggal 25 Juni 2021. Tim pelaksana melakukan koordinasi dengan kelompok pembudidaya udang vaname "Pantai Palie" Desa Madello, Kecamatan Balusu, Kabupaten Barru Provinsi Sulawesi Selatan untuk melakukan penyuluhan dan pelatihan mengenai penggunaan prebiotik Bio-MOS dalam pengkayaan pakan untuk larva udang vanname. Hasil koordinasi dengan mitra, disepakati kegiatan penyuluhan dan pelatihan akan dilakukan pada hari Kamis tanggal 8 Juli 2021.

Tim pelaksana memberikan penyuluhan dan pelatihan kepada anggota kelompok pembudidaya udang vaname sistem backyard "Pantai Palie" pada hari Kamis tanggal 8 Juli 2021, bertempat di rumah pak Zakaria (ketua kelompok "Pantai Palie"). Materi penyuluhan dan pelatihan dibawakan oleh Dr. Hamsah S.Pi.,M.Si sedangkan tim pelaksana yang lain ikut membantu terlaksananya proses pelatihan dengan baik. Antusias peserta sangat tinggi terhadap materi yang disampaikan, karena selama ini anggota kelompok menggunakan pakan alami Artemia sp. tanpa perlakuan (pengkayaan) terlebih dahulu.
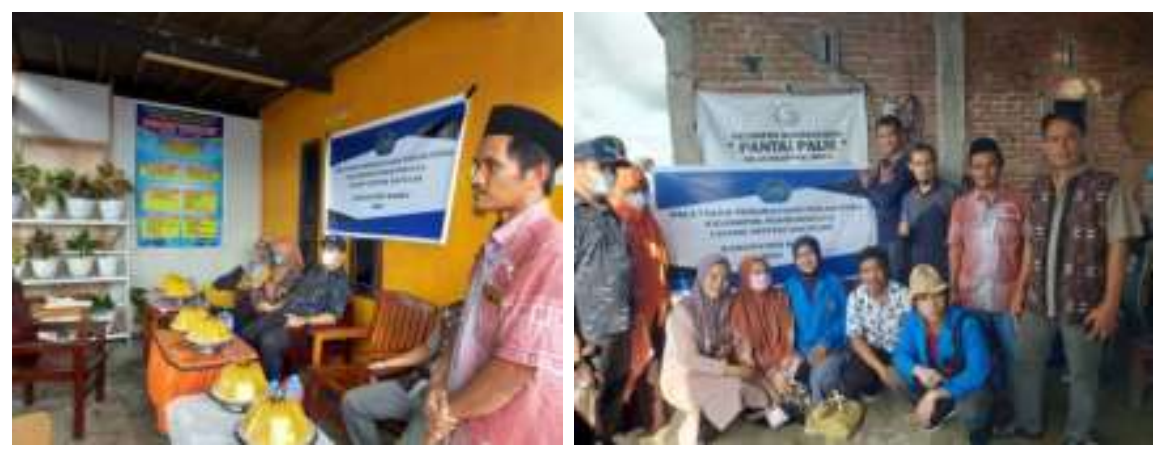

Gambar 1. Acara penyambutan oleh ketua kelompok Pantai Palie (kiri) dan berfoto bersama dengan mahasiswa yang ikut dalam kegiatan pengabdian pada masyarakat (kanan).

Saat pelatihan berlangsung, diberikan informasi mengenai fungsi dan peran pengkayaan Artemia sp. dengan Bio-MOS, yaitu untuk meningkatkan kualitas pakan serta berfungsi meningkatkan sistem pencernaan udang vanname. Peran prebiotik Bio-MOS dapat meningkatkan peran probiotik dalam saluran cerna, sehingga memudahkan udang mencerna pakan melalui bantuan dari aktivitas sejumlah bakteri tertentu yang menguntungkan (probiotik) di usus udang dengan tujuan untuk meningkatkan pertumbuhan, kelulushidupan dan resistensi 
udang terhadap pathogen (Cerezuela dkk, 2011, Febrianti dkk, 2016, dan Hayati, 2019).

Sebelum dilakukan bioenkapsulasi, siste Artemia sp. terlebih dahulu ditetaskan dalam wadah penetasan yang dilengkapi sistem aerasi selama \pm 24 hingga 28 jam tergantung kualitas siste yang digunakan. Selanjutnya naupli Artemia sp. dipanen dan dibilas air laut bersih untuk menghilangkan cangkang siste sisa penetasan, lalu dimasukkan dalam wadah pengkayaan (bioenkapsulasi) yang juga dilengkapi sistem aerasi. Bioenkapsulasi dilakukan dengan cara menambahkan Bio-MOS ke dalam wadah pengkayaan naupli Artemia sp. sebanyak $12 \mathrm{mg} / \mathrm{L}$ selama 4 jam. Naupli Artemia sp. hasil bioenkapsulasi kemudian dipanen dengan cara disaring menggunakan plankton net, lalu diberikan pada larva udang vanname sebanyak 8-10 individu/larva (Nimrat dkk. 2011), dan lebihnya disimpan dalam lemari pendingin pada suhu $4^{\circ} \mathrm{C}$ untuk penggunaan selanjutnya di hari yang sama.
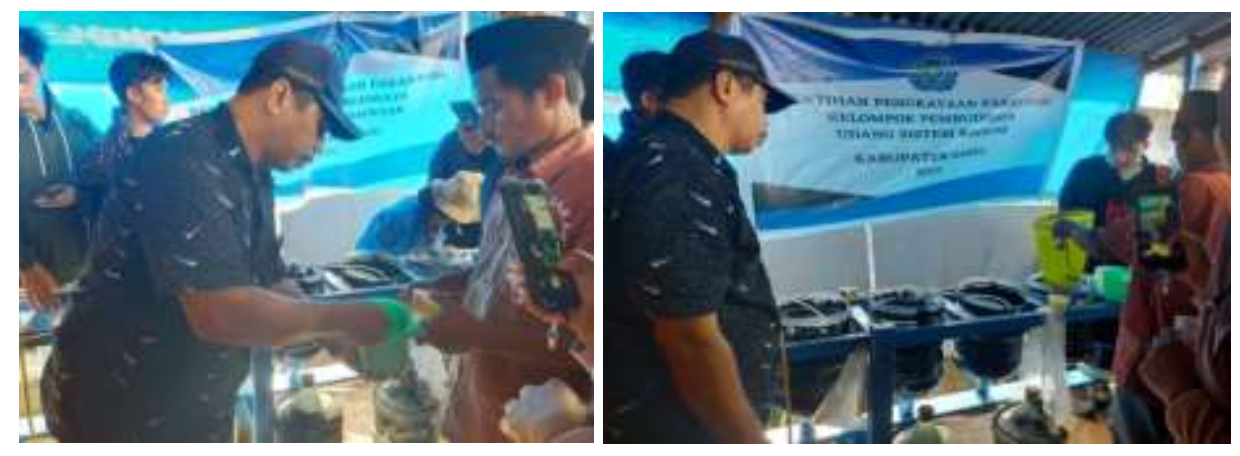

Gambar 2. Proses pemberian prebiotik Bio-MOS pada naupli Artemia sp.

Hasil di lapangan, ditemukan masyarakat masih belum mengetahui cara pengkayaan pakan alami Artemia sp. dengan memanfaatkan prebiotik Bio-MOS, sehingga sangat dibutuhkan pemahaman dan peningkatan keterampilan pembuatan pakan alami bernutrisi tinggi. Berdasarkan hasil diskusi, pemanfaatan wilayah pesisir sebagai lahan budidaya udang sistem backyard sangat berpotensi membuka lapangan pekerjaan bagi masyarakat, khususnya masyarakat di sekitar pinggir pantai dan telah mengurangi jumlah pengangguran. Budidaya udang dengan sistem backyard ini penting bagi masyarakat sebagai lahan mencari nafkah untuk menambah penghasilan ekonomi keluarga. Menurut hasil penelitian Zamzam (2018) bahwa masyarakat Desa Madello memiliki motifasi yang kuat untuk meningkatkan taraf hidupnya melalui pemanfaatan sumberdaya alam.

Selain memberikan penyuluhan dan pelatihan tentang pengkayaan pakan Artemia sp. dengan mannanoligisakarida (Bio-MOS), tim pelaksana juga mendapatkan feedback dari peserta pelatihan berupa angket mengenai beberapa pertanyaan sebelum dan sesudah pelatihan dilaksanakan. 
Tabel 1 : Data perbandingan rata-rata nilai setiap pernyataan angket sebelum dan sesudah pelatihan:

\begin{tabular}{clcc}
\hline No. & \multicolumn{1}{c}{ Pernyataan } & $\begin{array}{c}\text { Sebelum } \\
\text { Penyuluhan }\end{array}$ & $\begin{array}{c}\text { Setelah } \\
\text { Penyuluhan }\end{array}$ \\
\hline 1. & $\begin{array}{l}\text { Pengetahuan jenis-jenis prebiotik dan } \\
\text { probiotik }\end{array}$ & 2 & 2,80 \\
\hline 2. & $\begin{array}{l}\text { Pengetahuan fungsi dan peran } \\
\text { prebiotik dan probiotik }\end{array}$ & 2 & 2,80 \\
\hline 3. & $\begin{array}{l}\text { Pengetahuan tehnik pengkayaan pakan } \\
\text { alami }\end{array}$ & 1 & 3.00 \\
\hline 4. & $\begin{array}{l}\text { Pengetahuan tehnik penggunaan Bio- } \\
\text { MOS }\end{array}$ & 1 & 3.00 \\
\hline 5. & $\begin{array}{l}\text { Pengetahuan tehnik penggunaan pakan } \\
\text { alami setelah proses pengkayaan } \\
\text { nutrisi }\end{array}$ & 1 & 3.00 \\
\hline
\end{tabular}

Angket diberikan kepada pembudidaya udang sebelum dan sesudah pelatihan berlangsung untuk mengetahui dan mengukur pemahaman peserta tentang materi yang diberikan. Skala nilai dari setiap pertanyaan yaitu dimulai dari skala 1 dengan kategori belum mengetahui, skala 2 kategori cukup mengetahui dan skala 3 dengan kategori sudah mengetahui (Pamungkas dkk, 2020).

Berdasarkan hasil angket, nila rata-rata pengetahuan dan keterampilan peserta sebelum dilaksanakan pelatihan berada pada skala 1,4. Namun setelah dilaksanakan pelatihan, pengetahuan dan keterampilan kelompok pembudidaya udang menjadi meningkat, khusunya pada pernyataan no. 3, 4 dan 5 dari kategori belum mengetahui menjadi sudah mengetahui.

\section{Kesimpulan}

Berdasarkan hasil kegiatan pengabdian kepada masyarakat yang dilaksanakan pada kelompok pembudidaya udang vaname "Pantai Palie" di wilayah pesisir Desa Madello Kecamatan Balusu Kabupaten Barru, dapat disimpulkan bahwa selama ini kelompok pembudidaya "Pantai Palie" menggunakan pakan alami khususnya Artemia sp. dengan cara pemberian langsung ke larva udang vanname tanpa proses pengkayaan (bioenkapsulasi). Melalui kegiatan pelatihan ini, anggota kelompok "Pantai Palie" menjadi mengetahui dan terampil dalam tehnik pengkayaan pakan alami Artemia sp. dengan Bio-MOS. Sebelum pelatihan, pengetahuan dan keterampilan peserta berada pada skala nilai 1,4 (belum mengetahui) dan setelah pelatihan meningkat menjadi 3 (sudah mengetahui). Saran yang diberikan dalam kegiatan ini adalah sebaiknya dilakukan pendampingan lanjutan terkait penggunaan Bio-MOS pada pakan Artemia sp. serta pelatihan manajemen usaha untuk meningkatkan kualitas 
sumberdaya manusia sebagai pengelola pada usaha pembenihan sistem backyard di Desa Madello, Kabupaten Barru.

\section{Ucapan Terimakasih}

Ucapkan terima kasih disampaikan pada semua pihak yang telah membantu tim pelaksanan selama kegiatan berlangsung. Secara khusus ucapan terimakasih disampaikan kepada kepala Desa Madello dan kelompok pembudidaya udang vaname "Pantai Palie" yang telah bekerjasama dengan baik dalam proses pelatihan sehingga kegiatan ini dapat berjalan dengan optimal.

\section{Daftar Pustaka}

Cerezuela, R., Meseguer, J., \& Esteban, M. A. (2011). Current knowledge in synbiotic use for fish aquaculture: a review. Journal of Aquaculture Research \& Development $S, 1,1-7$.

Febrianti, D., \& Yuhana, M. (2016). Dietary synbiotic microcapsule influence the immune responses, growth performance and microbial populations to white spot syndrome virus in pacific white shrimp (Litopenaeus vannamei). Journal of Fisheries and Aquatic Science, 11(1), 28.

Hayati, N. 2019. Sintasan dan Total Bakteri Larva Udang Vaname (Litopenaeus vannamei) yang diberi Mannanoligosakarida (MOS) dengan Dosis yang berbeda melalui Artemia sp. Program Studi Budidaya Perairan Fakultas Pertanian Universitas Muhammadiyah Makassar (Skripsi).

Hamsah, H., Widanarni, W., Alimuddin, A., Yuhana, M., \& Junior, M. Z. (2018). Kinerja Pertumbuhan dan Respons Imun Larva Udang Vaname yang diberi Probiotik Pseudoalteromonas piscicida dan Prebiotik Mannanoligosakarida melalui Bioenkapsulasi Artemia sp. Prosiding Simposium Nasional Kelautan dan Perikanan, (5).

Hamsah, H., Widanarni, W., Alimuddin, A., Yuhana, M., Junior, M. Z., \& Hidayatullah, D. (2019). Immune response and resistance of Pacific white shrimp larvae administered probiotic, prebiotic, and synbiotic through the bio-encapsulation of Artemia sp. Aquaculture International, 27(2), 567-580.

Jayadi, J., Asni, A., Ilmiah, I., \& Rosada, I. (2021). Pengembangan Usaha Kampus Melalui Inovasi Teknologi Budidaya Ikan Nila Dengan Sistem Modular pada Kolam Terpal Di Kabupaten Pangkajene Kepulauan. To Maega: Jurnal Pengabdian Masyarakat, 4(2), 196-207.

Mahasri, G., Sudarno, S., \& Masithah, E. D. (2014). Ibm Bagi Petani Benih Udang Windu Skala Rumah Tangga (Backyard) Di Desa Kalitengah Kecamatan Tanggulangin Sidoarjo Yang Mengalami Gagal Panen Berkepanjangan Karena Serangan Penyakit [Ibm For Seed Shrimp Farmers Family Scale (Backyard) In Kalitengah Village, Tanggulangin District, Sidoarjo Region, That Harvesting Lossed To Long Times That Caused By The Diseases]. Jurnal Ilmiah Perikanan dan Kelautan, 6(1), 31-36.

Nimrat, S., Boonthai, T., \& Vuthiphandchai, V. (2011). Effects of probiotic forms, compositions of and mode of probiotic administration on rearing of Pacific 
white shrimp (Litopenaeus vannamei) larvae and postlarvae. Animal feed science and technology, 169(3-4), 244-258.

Pamungkas, P. B., \& Ardiyanta, A. (2020). Meningkatkan Pemahaman akan Pengendalian OPT Bawang Putih pada Anggota Kelompok Tani Ngudi Rahayu. To Maega: Jurnal Pengabdian Masyarakat, 3(2), 104-110.

Panjaitan, A. S., Hadie, W., \& Harijati, S. (2015). Penggunaan Chaetoceros calcitrans, Thalassiosira weissflogii dan Kombinasinya pada Pemeliharaan Larva Udang Vaname (Litopenaeus vannamei, Boone 1931). Berita Biologi, 14(3), 235-240

Zamzam, Z., Herman, H., \& Sunusi, S. (2018). Faktor Yang Mempengaruhi Tingkat Kemiskinan di Desa Madello Kecamatan Balusu Kabupaten Barru (Doctoral dissertation, UNIVERSITAS NEGERI MAKASSAR). 